\title{
Variation in outcome of invasive mechanical ventilation between different countries for patients with severe COVID- 19: a systematic review and meta-analysis
}

Hany Hasan Elsayed ( $\nabla$ hanyhassan77@hotmail.com )

Ain Shams University Faculty of Medicine

Aly Sherif Hassaballa

Ain Shams University

Taha Aly Ahmed

Ain Shams University Faculty of Medicine

Mohamed Gumaa

Ain Shams University

Hazem Youssef Sharkawy

Ain Shams University

\section{Research}

Keywords: COVID 19, invasive, mechanical ventilation

Posted Date: August 5th, 2020

DOI: https://doi.org/10.21203/rs.3.rs-52224/v1

License: (c) (1) This work is licensed under a Creative Commons Attribution 4.0 International License. Read Full License 


\section{Abstract}

Background: COVID 19 is the most recent cause of Adult respiratory distress syndrome ARDS. Invasive mechanical ventilation IMV can support gas exchange in patients failing non-invasive ventilation, but its reported outcome is highly variable between countries. We conducted a systematic review and meta-analysis on IMV for COVID-associated ARDS to study its outcome among different countries.

Methods: CENTRAL, MEDLINE/PubMed, Cochrane Library, and Scopus were systematically searched from June 82019 to June 8, 2020. Studies reporting five or more patients with end point outcome for severe COVID 19 infection treated with IMV were included. The main outcome assessed was mortality. Baseline, procedural, outcome, and validity data were systematically appraised and pooled with random-effect methods. Subgroup analysis for different countries was performed. Meta-regression for the effect of study timing and patient age and were tested. Publication bias was examined. This trial was registered with PROSPERO under registration number CRD42020190365

Findings: Our electronic search retrieved 4770 citations, 103 of which were selected for full-text review. Twenty-one studies with a combined population of 37359 patients with COVID-19 fulfilled the inclusion criteria. From this population, 5800 patients were treated by invasive mechanical ventilation. Out of those, 3301 patients reached an endpoint of ICU discharge or death after invasive mechanical ventilation while the rest were still in the ICU. Mortality from IMV was highly variable among the included studies ranging between $21 \%$ and $100 \%$. Random-effect pooled estimates suggested an overall in-hospital mortality risk ratio of 0.70 (95\% confidence interval 0.608 to $0.797 ; 12=98 \%)$. Subgroup analysis according to country of origin showed homogeneity in the 8 Chinese studies with high pooled mortality risk ratio of $0.97(12=24 \%, p=0.23)(95 \% \mathrm{Cl}=$ 0.94-1.00), similar to Italy with a low pooled mortality risk ratio of $0.26(95 \% \mathrm{Cl} 0.08-0.43)$ with homogeneity $(p=0.86)$ while the later larger studies coming from the USA showed pooled estimate mortality risk ratio of $0.60(95 \% \mathrm{Cl} 0.43-0.76)$ with persistent heterogeneity $(I 2=98 \%, p<0.001)$. Meta-regression showed that outcome from IMV improved with time $(p<0.001)$. Age had no statistically significant effect on mortality $(p=0.102)$. Publication bias was excluded by visualizing the funnel plot of standard error, Egger's test with $p=0.714$ and Begg\&Mazumdar test with $p=0.334$

Interpretation: The study included the largest number of patients with outcome findings of IMV in this current pandemic. Our findings showed that the use of IMV for selected COVID 19 patients with severe ARDS carries a high mortality, but outcome has improved over the last few months and in more recent studies. The results should encourage physicians to use this facility when indicated for severely ill COVID-19 patients.

\section{Introduction}

Coronavirus disease 2019 (COVID-19) is a viral respiratory tract infection caused by a coronavirus which was first documented in Wuhan, China, in December 2019 (1)

After then, this outbreak spread globally and has been considered as a pandemic and an international public health emergency by the WHO on March 11,2020. As of 14th of July 2020, a cumulative total of 13,560,323 confirmed cases of coronavirus disease 2019 (COVID-19) were reported with total 583,523 deaths in 203 countries and territories worldwide (2). Currently, there is neither a proven effective medication nor a vaccine has been discovered for the COVID-19 infection.

Although most patients with COVID-19 infection have only mild or uncomplicated course, around 10-20\% will develop a severe disease that necessitates hospitalization and oxygen therapy or even ICU admission and progression to acute respiratory distress syndrome (ARDS). The prevalence of ARDS caused by COVID-19 is around $8.2 \%$ who will require mechanical ventilation and prone positioning (3).

Invasive mechanical ventilation is lifesaving in severe respiratory failure not responding to other less invasive modalities, and few medical therapies equal its power. While some COVID-19 patients can be managed with supplemental oxygen and noninvasive mechanical ventilation, patients with the most severe respiratory failure demand insertion of an endotracheal tube.

Page 2/16 
An endotracheal tube facilitates control over an unstable airway and enables precise regulation of oxygen, pressure and volume but inevitably, the endotracheal tube brings in its wake a list of complications aggravated by the morbidity of the patient's other system failures. Each day of mechanical ventilation exposes patients to complications and increases mortality (4).

In view of the current growing pandemic and the fact that there is high variability in published data for the outcome of invasive mechanical ventilation IMV to support COVID-19 patients, we aimed to estimate the effect of IMV on mortality from COVID-19 patients with respiratory failure via all available studies by performing a systematic review and meta-analysis.

\section{Methods}

\section{Search strategy and selection criteria}

This systematic review complies with the Meta-analysis Of Observational Studies in Epidemiology (MOOSE) and Preferred Reporting Items for Systematic Reviews and Meta-Analyses (PRISMA) guidelines. We electronically ran a search on CENTRAL, MEDLINE/PubMed, Cochrane Library, and Scopus. On Pubmed the word search used was (COVID OR SARS COV2 OR pandemic) AND (ARDS) OR (acute respiratory distress syndrome) (Intensive care unit) OR (ICU) OR (Intensive therapy unit) OR (ITU) OR (acute lung injury) OR (respiratory failure) OR (respiratory insufficiency) OR (mechanical ventilation) OR (invasive ventilation)).

We searched trial registries, included the grey literature, and used studies accepted and ahead of print. We did our search up to $8^{\text {th }}$ of June 2020 using a one-year filter option without language restrictions. We used both subject headings and text word terms to search for articles about mechanical ventilation with ARDS in COVID-19 patients. Inclusion criteria were (all criteria should be concomitantly met for study inclusion): a) study reporting on 5 or more patients with final outcomes; b) with confirmed COVID 19 infection; c) receiving invasive mechanical ventilation. Exclusion criteria were (one criterion was sufficient for study exclusion): a) inclusion of $<5$ patients with COVID-19 infection treated with IMV (thereby, any study reporting on fewer than 5 patients or case reports treated with IMV were excluded); b) duplicate publication (in which case only the most recent report from the same study group was included in the systematic review). Use of a sample size cut-off was chosen to limit the risk of imprecision and publication bias c) studies with insufficient data about the outcome endpoints (mortality and ICU discharge). AH, TA and HY independently reviewed the titles and abstracts of all citations. Then, they independently reviewed the full text of both definite and potentially eligible studies for inclusion. Disagreements were reviewed by a fourth reviewer HE, who had a deciding vote. The study protocol link is at www.crd.yorl.ac.uk/PROSPERO under registration number CRD42020190365

\section{Data analysis}

A single arm meta-analysis was conducted to examine the mortality incidence in invasive mechanical ventilation treatment for COVID 19. Data were summarized using the risk ratio (95\% confidence interval (CI)). The data were pooled using DerSimonian-Laird random effects model (5). P value of 0.05 or less was statistically significant. Cochran Q and I2 were used to assess heterogeneity between studies. The degree of heterogeneity was categorized as either low ( $12<25 \%)$, moderate (I2 $=25 \%-75 \%)$, or high (I2 > 75\%) (6). A P value of $\leq 0.05$ indicated significant heterogeneity. A subgroup meta-analysis according to the study's country of origin was conducted to investigate the high heterogeneity detected. The data used in the meta-analysis in each study were the number of mortality events and the number of closed cases (either ICU discharged or dead). The study of the outcome in relation to the time of each study was performed by calculating a median number representing the central timing of the study. Timing was calculated over 180 days (from 1-180) starting at the beginning of December 2020 to the end of May 2020 (6 x 30 days) and each study was given a range of days starting from the first to the last day as recorded in the study duration. A median number was calculated for the time range of each study (available for 20 out of 21 studies). This was done to avoid time overlap and duration bias between different studies. Publication bias was 
examined by visual inspection of the funnel plot and tested by Egger's test and Begg and Mazumdar test. A P value of $\leq 0.05$ indicated the existence of publication bias. All analyses were performed using Open Meta Analyst software Windows 10 version.

\section{Role of funding source}

There was no funding source for this study. The corresponding author of this study had full access to all the study data and had final responsibility for the decision to submit the manuscript for publication.

\section{Results}

Our electronic search retrieved 4770 citations, 103 of which were selected for full-text review (Figure 1). Twenty-one studies (7-27) with a combined population of 37359 patients fulfilled the inclusion criteria. From this population, 5800 patients were treated by invasive mechanical ventilation. Out of those, 3301 patients reached an endpoint of ICU discharge or death after invasive mechanical ventilation while the rest were still in the ICU (regardless of mechanical ventilation state). All studies are summarized in Table 1.

Mortality from IMV was highly variable among the included studies ranging between $21 \%$ and $100 \%$. Random-effect pooled estimates suggested an overall in-hospital mortality risk ratio of 0.70 ( $95 \%$ confidence interval 0.608 to $0.797 ; 12=98 \%$ )

(Figure 2). Most of the preliminary studies were from China (eight studies with 203 patients with endpoints). Larger studies then followed from the USA, Italy, Denmark, UK, Canada, Japan and France (thirteen studies with 3098 patients with endpoints). Only six studies $(29 \%)(9,14,16-19)$ reported complete outcome endpoints for all patients who received IMV while the rest of studies had patients who did not reach an endpoint.

To investigate the overall inter-study heterogeneity, a subgroup analysis was performed according to the country of origin of each study (Figure 3) This showed homogeneity in the 8 Chinese studies with high pooled mortality risk ratio of 0.97 (I2 = $24 \%, p=0.23)(95 \% \mathrm{Cl}=0.94-1.00)$, similar to Italy with a low pooled mortality risk ratio of $0.26(95 \% \mathrm{Cl} 0.08-0.43)$ with homogeneity $(p=0.86)$ while the later larger studies coming from the USA showed pooled estimate mortality risk ratio of 0.60 $(95 \% \mathrm{Cl} 0.43-0.76)$ with persistent heterogeneity $(12=98 \%, p<0.001)$.

To investigate the effect of the study time on the outcome, a meta-regression analysis of the median day of the study duration showed that mortality was lower as the study time was more recent $(p<0.001)$ (Figure 4). Analysis of the effect of age on mortality showed no statistical significance $(p=0.102)$. Publication bias was excluded by visualizing the funnel plot of standard error (Figure 5), Egger's test with $p=0.714$ and Begg\&Mazumdar test with $p=0.334$

\section{Discussion}

The mortality of IMV related for COVID-19 patients reported from different studies may vary according to the denominator used. For example, in the study by Richardson and colleagues from New York, the denominators excluded patients who were still mechanically ventilated in the ICU (11), but Graselli and his colleagues (12) from Italy, included those in the ICU in the denominator and the abstract for the data by Richardson and his colleagues has since been corrected to report the percentage of patients alive, dead, and still in the ICU to try to avoid this misinterpretation.

Preliminary reports from China regarding IMV for COVID-19 patients were obviously dismal as shown by our subgroup analysis with a median mortality of $97 \%$ (95\% Cl 94-100\%). All the following studies apart from Richardson et al (11) showed acceptable mortality rates (21\%-69\%) and this should change the perception for this crucial intervention. The misconception that all patients on IMV will die is the rule for all COVID-19 patients does not do good for anyone. Our headlines extolling that IMV mortality rate for COVID-19 are in the range of $90-100 \%$ makes the medical team wonder if it's worth risking their lives while dealing with such a futile intervention. The concern of families seeing their beloved ones ventilated after being infected 
will turn into nothing but terror. Additionally, countries with limited resources and ICU beds might not even bother procuring their ventilators in the era of an accelerating pandemic.

The outcome of IMV for patients with COVID-19 was not much worse than the previous respiratory virus pandemics. In a pooled mortality calculation from 3 studies (28-30) the outcome of invasive mechanical ventilation for treating patients with Middle East Respiratory syndrome MERS was a mortality of $77 \%$ (647/840).

Timing of placing patients with severe COVID-19 on mechanical ventilation will vary. Mortality may have been lower if patients were placed on a ventilator earlier in their disease course. On the other hand, the denominator may be smaller where patients with respiratory failure were not offered mechanical ventilation in severe COVID-19. This may be due to family wishes, generous use of noninvasive ventilation or the scarcity of ventilator beds in a hastening pandemic. We have never been able to agree on triggers for ventilatory support, even with diseases that are much better known and understood than COVID-19.

Mortality from COVID-19 has been reported to be age-dependent, and variations in population age or the age of admitted patients are likely to have a significant influence on mortality. Similar arguments may apply for comorbidities (31) As we have only summary statistics, with variable reporting, we were unable to explore these factors in detail, though meta regression by the crude measure of average age was not significantly associated with reported mortality in our analysis. Reporting of such data in future cohort studies and trials would be beneficial

The current indication to place a patient with severe COVID-19 on invasive mechanical ventilation is not a clear-cut one and neither are the outcomes. Most published reports $(15 / 21=71 \%)$ in our analysis did not include full endpoints for all patients receiving IMV as they were still receiving IMV or still in the ICU so the assessment of the final outcome of IMV for these centres is not possible. We may not fully understand how or why these outcome data from each country look different but as our understanding of the COVID-19 improves over months, this may improve the outcome as our meta regression has shown.

So, while we scrutinize these published reports and try to extract what is universal and can be applied to our understanding and care of patients locally, we need to recognize and report on the enormous drivers of differences and be vigilant in presentation of data to minimize confusion in interpretation. The variability of findings has always existed in studies of IMV for critically ill patients and COVID-19 is not an exception, merely an amplifier of these differences.

\section{Limitations}

In our interpretation we excluded all patients still receiving care in the ICU to avoid the use estimated mortality with all its drawbacks and included only patients discharged from the ICU in the denominator. Obviously, this carries the risk of not including patients deteriorating outside the ICU after discharge or needing readmission after ICU discharge. A proportion of patients surviving ICU will die before hospital discharge and the survival rate we report will modestly overestimate survival to hospital discharge. To put this in context, the long-running ICNARC case mix registry reports a $5.7 \%$ in-hospital mortality rate for all patients after discharge from ICU (32). Whether this finding is replicated after ICU discharge with COVID-19 is worthy of future research, as are the longer-term outcomes of these patients. Bias from mortality results can be due different "inclusion/exclusion" criteria for mechanical ventilation across institutions resulting in different populations being compared and varying availability of resources including mechanical ventilators affecting outcomes in undetermined ways. Several studies in our analysis were excluded as they did not specifically report ICU outcome data; rather they included outcome data for the entire inpatient population, or outcome data were not yet available. It is possible that the ICU outcomes in these studies may have differed from the studies we were able to include in this analysis.

\section{Conclusion}


In conclusion, the study included the largest number of patients with outcome findings of IMV in this current pandemic. Our findings showed that the use of IMV for selected COVID 19 patients with severe ARDS carries a high mortality, but outcome has improved over the last few months and in more recent studies indicating a probable better understanding of the disease management. The results could encourage physicians to use this facility when indicated for severely ill COVID-19 patients to save lives despite marked differences in practice and outcomes between different countries.

\section{Abbreviations}

ARDS: Adult respiratory distress syndrome, IMV :Invasive mechanical ventilation

ICU: Intensive care unit, MERS :Middle east respiratory syndrome

\section{Declarations}

\section{Consent for publication}

All authors consent for publication

\section{Author contribution}

HHE conceived the study, which was overseen by MG. ASH, TA, and HY devised the search strategy, executed the search, and selected the studies for inclusion. ASH, TH, HY and HHE extracted the data, which were analysed by MG. All authors were involved in development of the methodological approach. HHE, ASH, TA and HY wrote the article, which was reviewed and revised by all authors.

\section{Declaration of interests}

None

\section{Acknowledgments}

None

\section{Availability of data and material}

All data and material available on request

\section{Ethics approval and consent to participate}

Not applicable

\section{Funding}

No funding source

\section{References}


1. [The epidemiological characteristics of an outbreak of 2019 novel coronavirus diseases (COVID-19) in China]. Zhonghua Liu Xing Bing Xue Za Zhi 2020; 41: 145-51.

2. Coronavirus disease (COVID-19) Situation Report - 107. World Heal Organ 2020; 2019: 2633.

3. Surveillances V. The epidemiological characteristics of an outbreak of 2019 novel coronavirus diseases (COVID-19) in China. Zhonghua Liu Xing Bing Xue Za Zhi 2020; 41: 145-51.

4. Tobin MJ. Basing respiratory management of COVID-19 on physiological principles. Am J Respir Crit Care Med. 2020;201(11):1319-20

5. DerSimonian R, Laird N. Meta-analysis in clinical trials. Control Clin Trials 1986;7:177-88.

6. Higgins JP, Thompson SG, Deeks JJ, Altman DG. Measuring inconsistency in meta-analyses. BMJ. 2003;327: 557-560.

7. Wang J, Lu F, Zhou M, Qi Z, Chen Z. [Tracheal intubation in patients with severe and critical COVID-19: analysis of 18 cases]. Nan Fang Yi Ke Da Xue Xue Bao 2020; 40: 337-41.

8. Pedersen HP, Hildebrandt T, Poulsen A, et al. Initial experiences from patients with COVID-19 on ventilatory support in Denmark. Dan Med J 2020; 67.

9. Chen T, Wu D, Chen H, et al. Clinical characteristics of 113 deceased patients with coronavirus disease 2019: retrospective study. BMJ 2020; 368. DOI:10.1136/bmj.m1091.

10. Yu Y, Xu D, Fu S, et al. Patients with COVID-19 in 19 ICUs in Wuhan, China: a cross-sectional study. Crit Care 2020; 24 : 219.

11. Richardson S, Hirsch JS, Narasimhan M, et al. Presenting Characteristics, Comorbidities, and Outcomes Among 5700 Patients Hospitalized With COVID-19 in the New York City Area. JAMA 2020; published online April.

DOI:10.1001/jama.2020.6775.

12. Grasselli G, Zangrillo A, Zanella A, et al. Baseline Characteristics and Outcomes of 1591 Patients Infected With SARSCoV-2 Admitted to ICUs of the Lombardy Region, Italy. JAMA 2020; published online April. DOI:10.1001/jama.2020.5394.

13. Zangrillo A, Beretta L, Scandroglio AM, et al. Characteristics, treatment, outcomes and cause of death of invasively ventilated patients with COVID-19 ARDS in Milan, Italy. Crit care Resusc J Australas Acad Crit Care Med 2020; published online April.

14. Bhatraju PK, Ghassemieh BJ, Nichols M, et al. Covid-19 in Critically III Patients in the Seattle Region - Case Series. N Engl J Med 2020; 382: 2012-22.

15. Kato H, Shimizu H, Shibue Y, et al. Clinical course of 2019 novel coronavirus disease (COVID-19) in individuals present during the outbreak on the Diamond Princess cruise ship. J Infect Chemother Off J Japan Soc Chemother 2020; 26: 865-9.

16. Wu C, Chen X, Cai Y, et al. Risk Factors Associated With Acute Respiratory Distress Syndrome and Death in Patients With Coronavirus Disease 2019 Pneumonia in Wuhan, China. JAMA Intern Med 2020; published online March. DOI:10.1001/jamainternmed.2020.0994.

17. Yang $X, Y u Y, X u$ J, et al. Clinical course and outcomes of critically ill patients with SARS-CoV-2 pneumonia in Wuhan, China: a single-centered, retrospective, observational study. Lancet Respir Med 2020; 2600: 1-7.

18. Ruan Q, Yang K, Wang W, Jiang L, Song J. Correction to: Clinical predictors of mortality due to COVID-19 based on an analysis of data of 150 patients from Wuhan, China (Intensive Care Medicine, (2020), 10.1007/s00134-020-05991-x). Intensive Care Med 2020. DOI:10.1007/s00134-020-06028-z.

19. Zhou F, Yu T, Du R, et al. Clinical course and risk factors for mortality of adult inpatients with COVID-19 in Wuhan, China: a retrospective cohort study. Lancet (London, England) 2020; 395: 1054-62.

20. Cummings MJ, Baldwin MR, Abrams D, et al. Epidemiology, clinical course, and outcomes of critically ill adults with COVID-19 in New York City: a prospective cohort study. Lancet (London, England) 2020; 395: 1763-70.

21. Xu PP, Tian RH, Luo S, et al. Risk factors for adverse clinical outcomes with COVID-19 in China: a multicenter, retrospective, observational study. Theranostics 2020; 10: 6372-83. 
22. Argenziano MG, Bruce SL, Slater CL, et al. Characterization and clinical course of 1000 patients with coronavirus disease 2019 in New York: retrospective case series. BMJ 2020; 369: m1996.

23. Mitra AR, Fergusson NA, Lloyd-Smith E, et al. Baseline characteristics and outcomes of patients with COVID-19 admitted to intensive care units in Vancouver, Canada: a case series. C Can Med Assoc J = J l'Association medicale Can 2020; 192: E694-701.

24. Auld SC, Caridi-Scheible M, Blum JM, et al. ICU and Ventilator Mortality Among Critically III Adults With Coronavirus Disease Crit Care Med 2020; published online May. DOI:10.1097/CCM.0000000000004457.

25. Hur K, Price CPE, Gray EL, et al. Factors Associated With Intubation and Prolonged Intubation in Hospitalized Patients With COVID-19. Otolaryngol neck Surg Off J Am Acad Otolaryngol Neck Surg 2020; 163: 170-8.

26. Petrilli CM, Jones SA, Yang J, et al. Factors associated with hospital admission and critical illness among 5279 people with coronavirus disease 2019 in New York City: prospective cohort study. BMJ 2020; 369: m1966.

27. Docherty AB, Harrison EM, Green CA, et al. Features of 20133 UK patients in hospital with covid-19 using the ISARIC WHO Clinical Characterisation Protocol: prospective observational cohort study. BMJ 2020; 369: m1985.

28. Arabi YM, Al-Omari A, Mandourah Y, et al. Critically III Patients With the Middle East Respiratory Syndrome: A Multicenter Retrospective Cohort Study. Crit Care Med. 2017;45(10):1683-1695.

29. Arabi YM, Mandourah Y, Al-Hameed F, et al. Corticosteroid Therapy for Critically III Patients with Middle East Respiratory Syndrome. Am J Respir Crit Care Med. 2018;197(6):757-767.

30. Arabi YM, Deeb AM, Al-Hameed F, et al. Macrolides in critically ill patients with Middle East Respiratory Syndrome. Int J Infect Dis. 2019;81:184-190.

31. Intensive Care National Audit and Research Centre. ICNARC report on COVID-19 in critical care 29th May 2020, 2020. https://www.icnarc.org/Our-Audit/Audits/Cmp/Reports

32. Intensive Care National Audit and Research Centre. Case Mix Programme Summary Statistics 2018-2019, 2019. https://www.icnarc.org/Our-Audit/Audits/Cmp/Reports/Summary-Statistics

\section{Tables}

Table 1: Summary of all studies, N/A Not available 


\begin{tabular}{|c|c|c|c|c|c|c|c|c|c|}
\hline Author & Name & Country & Duration & Age & $\begin{array}{l}\text { No. of } \\
\text { patients }\end{array}$ & $\begin{array}{l}\text { No. } \\
\text { of } \\
\text { ARDS }\end{array}$ & $\begin{array}{l}\text { No. } \\
\text { of } \\
\text { IMV }\end{array}$ & Cure & Death \\
\hline $\begin{array}{l}\text { Wang et al } \\
\text { (7) }\end{array}$ & $\begin{array}{l}\text { Tracheal } \\
\text { intubation in } \\
\text { patients with } \\
\text { severe and } \\
\text { critical COVID- } \\
\text { 19: analysis of } \\
18 \text { cases }\end{array}$ & China & $\begin{array}{l}\text { From } \\
\text { February } \\
\text { 12th to } \\
\text { February } \\
\text { 28th }\end{array}$ & $70.39 \pm 8.02$ & 18 & N/A & 18 & 0 & 5 \\
\hline $\begin{array}{l}\text { Pedersen et } \\
\text { al (8) }\end{array}$ & $\begin{array}{l}\text { Initial } \\
\text { experiences } \\
\text { from patients } \\
\text { with COVID- } \\
19 \text { on } \\
\text { ventilatory } \\
\text { support in } \\
\text { Denmark. }\end{array}$ & Denmark & $\begin{array}{l}\text { From } 11 \\
\text { March } \\
2020 \text { to } \\
01 \text { April } \\
2020\end{array}$ & $\begin{array}{l}69.5 \text { years } \\
\text { (range: } 56- \\
84 \text { years) }\end{array}$ & 16 & 16 & 16 & 4 & 7 \\
\hline $\begin{array}{l}\text { Chen et al } \\
\text { (9) }\end{array}$ & $\begin{array}{l}\text { Clinical } \\
\text { characteristics } \\
\text { of } 113 \\
\text { deceased } \\
\text { patients with } \\
\text { coronavirus } \\
\text { disease 2019: } \\
\text { retrospective } \\
\text { study }\end{array}$ & China & $\begin{array}{l}\text { From } 13 \\
\text { January } \\
\text { to } 12 \\
\text { February } \\
2020\end{array}$ & $\begin{array}{l}62.0(44.0- \\
70.0)\end{array}$ & 274 & 196 & 17 & 0 & 17 \\
\hline $\begin{array}{l}\text { Yu et al } \\
(10)\end{array}$ & $\begin{array}{l}\text { Patients with } \\
\text { COVID-19 in } 19 \\
\text { ICUs in Wuhan, } \\
\text { China: a cross- } \\
\text { sectional study }\end{array}$ & China & $\begin{array}{l}\text { February } \\
26 \text { to } 27, \\
2020\end{array}$ & $64(57-70$ & 226 & 161 & 121 & 0 & 79 \\
\hline $\begin{array}{l}\text { Richardson } \\
\text { et al (11) }\end{array}$ & $\begin{array}{l}\text { Presenting } \\
\text { Characteristics, } \\
\text { Comorbidities, } \\
\text { and Outcomes } \\
\text { Among } 5700 \\
\text { Patients } \\
\text { Hospitalized } \\
\text { With COVID-19 } \\
\text { in the New York } \\
\text { City Area }\end{array}$ & USA & $\begin{array}{l}\text { From } \\
\text { March 1, } \\
2020 \text { to } \\
\text { April 4, } \\
2020\end{array}$ & $\begin{array}{l}63 \text { years IQR } \\
52-75 ; \text { range }\end{array}$ & 5700 & N/A & 1151 & 38 & 282 \\
\hline $\begin{array}{l}\text { Grasseli et } \\
\text { al (12) }\end{array}$ & $\begin{array}{l}\text { Baseline } \\
\text { Characteristics } \\
\text { and Outcomes } \\
\text { of } 1591 \\
\text { Patients } \\
\text { Infected With } \\
\text { SARS-CoV-2 } \\
\text { Admitted to } \\
\text { ICUs of the } \\
\text { Lombardy } \\
\text { Region, Italy }\end{array}$ & Italy & $\begin{array}{l}\text { From } \\
\text { February } \\
20 \text { and } \\
\text { March 25, } \\
2020\end{array}$ & $\begin{array}{l}63(56-70) \\
\text { years }\end{array}$ & 1591 & N/A & 1150 & 256 & 405 \\
\hline $\begin{array}{l}\text { Zangrillo et } \\
\text { al (13) }\end{array}$ & $\begin{array}{l}\text { Characteristics, } \\
\text { treatment, } \\
\text { outcomes and } \\
\text { cause of death } \\
\text { of invasively } \\
\text { ventilated } \\
\text { patients with } \\
\text { COVID-19 ARDS } \\
\text { in Milan, Italy. }\end{array}$ & Italy & $\begin{array}{l}\text { From } 20 \\
\text { February } \\
\text { to } 2 \text { April } \\
2020\end{array}$ & $\begin{array}{l}\text { 61years } \\
\text { (interquartile } \\
\text { range [IQR], } \\
54-69 .\end{array}$ & 73 & 73 & 73 & 17 & 23 \\
\hline
\end{tabular}




\begin{tabular}{|c|c|c|c|c|c|c|c|c|c|}
\hline $\begin{array}{l}\text { Bhatraju } \\
\text { et al (14) }\end{array}$ & $\begin{array}{l}\text { Covid-19 in } \\
\text { Critically III } \\
\text { Patients in the } \\
\text { Seattle Region } \\
\text { - Case Series }\end{array}$ & USA & $\begin{array}{l}\text { From } \\
\text { February } \\
24 \text { to } \\
\text { March 9, } \\
2020\end{array}$ & Mean $64 \pm 18$ & 24 & 18 & 18 & 6 & 12 \\
\hline $\begin{array}{l}\text { Kato et al } \\
\text { (15) }\end{array}$ & $\begin{array}{l}\text { Clinical course } \\
\text { of } 2019 \text { novel } \\
\text { coronavirus } \\
\text { disease (COVID- } \\
\text { 19) in } \\
\text { individuals } \\
\text { present during } \\
\text { the outbreak on } \\
\text { the Diamond } \\
\text { Princess cruise } \\
\text { ship }\end{array}$ & Japan & $\begin{array}{l}\text { From } \\
\text { March } 11 \\
\text { to March } \\
19,2020\end{array}$ & 76 & 70 & N/A & 14 & 7 & 2 \\
\hline $\begin{array}{l}\text { Wu et al. } \\
\text { (16) }\end{array}$ & $\begin{array}{l}\text { Risk Factors } \\
\text { Associated with } \\
\text { Acute } \\
\text { Respiratory } \\
\text { Distress } \\
\text { Syndrome and } \\
\text { Death in } \\
\text { Patients with } \\
\text { Coronavirus } \\
\text { Disease } 2019 \\
\text { Pneumonia in } \\
\text { Wuhan, China }\end{array}$ & China & $\begin{array}{l}\text { From } \\
\text { December } \\
25,2019, \\
\text { to } \\
\text { February } \\
13,2020\end{array}$ & $51(43-60)$ & 210 & 84 & 5 & 0 & 5 \\
\hline $\begin{array}{l}\text { Yang et al } \\
\text { (17) }\end{array}$ & $\begin{array}{l}\text { Clinical course } \\
\text { and outcomes } \\
\text { of critically ill } \\
\text { patients with } \\
\text { SARS-CoV-2 } \\
\text { pneumonia in } \\
\text { Wuhan, China: a } \\
\text { single-centered, } \\
\text { retrospective, } \\
\text { observational } \\
\text { study. }\end{array}$ & China & $\begin{array}{l}\text { From late } \\
\text { December } \\
2019 \text { to } \\
\text { Jan 26, } \\
2020\end{array}$ & 59.7 (13.3) & 52 & 52 & 22 & 3 & 19 \\
\hline $\begin{array}{l}\text { Ruan et al. } \\
\text { (18) }\end{array}$ & $\begin{array}{l}\text { Correction to: } \\
\text { Clinical } \\
\text { predictors of } \\
\text { mortality due to } \\
\text { COVID-19 based } \\
\text { on an analysis } \\
\text { of data of } 150 \\
\text { patients from } \\
\text { Wuhan, China }\end{array}$ & China & $\mathrm{N} / \mathrm{A}$ & $\begin{array}{l}\text { Survivors: } \\
67 \text { (15-81) } \\
\text { Non- } \\
\text { Survivors: } \\
50 \text { (44-81) }\end{array}$ & 150 & 62 & 25 & 0 & 25 \\
\hline $\begin{array}{l}\text { Zhou et al } \\
\text { (19) }\end{array}$ & $\begin{array}{l}\text { Clinical course } \\
\text { and risk factors } \\
\text { for mortality of } \\
\text { adult inpatients } \\
\text { with COVID-19 } \\
\text { in Wuhan, } \\
\text { China: a } \\
\text { retrospective } \\
\text { cohort study. }\end{array}$ & China & $\begin{array}{l}\text { From Dec } \\
29,2019 \\
\text { to Jan } 31, \\
2020\end{array}$ & $56(46-67)$ & $\begin{array}{l}\text { female } \\
72 \\
(38 \%) \\
\\
\text { Male } \\
119 \\
(62 \%)\end{array}$ & 191 & 32 & 1 & 31 \\
\hline $\begin{array}{l}\text { Cummings } \\
\text { et al (20) }\end{array}$ & $\begin{array}{l}\text { Epidemiology, } \\
\text { Clinical Course, }\end{array}$ & USA & $\begin{array}{l}\text { From } 2 \\
\text { March to }\end{array}$ & $\begin{array}{l}62 \text { years } \\
\text { (IQR } 51-72)\end{array}$ & 1150 & 257 & 203 & 58 & 84 \\
\hline
\end{tabular}




\begin{tabular}{|c|c|c|c|c|c|c|c|c|c|}
\hline & $\begin{array}{l}\text { and Outcomes } \\
\text { of Critically III } \\
\text { Adults With } \\
\text { COVID-19 in } \\
\text { New York City: A } \\
\text { Prospective } \\
\text { Cohort Study }\end{array}$ & & $\begin{array}{l}28 \text { April } \\
, 2020\end{array}$ & & & & & & \\
\hline $\begin{array}{l}\text { Xu et al } \\
\text { (21) }\end{array}$ & $\begin{array}{l}\text { Risk factors for } \\
\text { adverse clinical } \\
\text { outcomes with } \\
\text { COVID-19 in } \\
\text { China: a } \\
\text { multicenter, } \\
\text { retrospective, } \\
\text { observational } \\
\text { study. }\end{array}$ & China & $\begin{array}{l}\text { From } \\
\text { January } \\
10,2020 \\
\text { and } \\
\text { March } 13\end{array}$ & $\begin{array}{l}46.1 \text { years } \\
\text { (SD 15.2) } \\
\text { (range } \\
\text { from } 2 \\
\text { months to } \\
86 \text { years } \\
\text { old), }\end{array}$ & $\begin{array}{l}382 \\
\text { males, } \\
321 \\
(46 \%) \\
\text { females }\end{array}$ & 703 & 20 & 4 & 14 \\
\hline $\begin{array}{l}\text { Argenziano } \\
\text { et al (22) }\end{array}$ & $\begin{array}{l}\text { Characterization } \\
\text { and clinical } \\
\text { course of } 1000 \\
\text { patients with } \\
\text { coronavirus } \\
\text { disease } 2019 \text { in } \\
\text { New York: } \\
\text { retrospective } \\
\text { case series }\end{array}$ & USA & $\begin{array}{l}\text { From } 11 \\
\text { March to } \\
6 \text { April } \\
2020\end{array}$ & $\begin{array}{l}\text { 63.0 IQR } \\
(50.0-75.0)\end{array}$ & $\begin{array}{l}\text { Male } \\
596 ; \\
59.6 \% \\
\text { Female } \\
\\
404 ; \\
40.4\end{array}$ & 1000 & 233 & 36 & 111 \\
\hline $\begin{array}{l}\text { Mitra et al } \\
\text { (23) }\end{array}$ & $\begin{array}{l}\text { Baseline } \\
\text { characteristics } \\
\text { and outcomes } \\
\text { of patients with } \\
\text { COVID-19 } \\
\text { admitted to } \\
\text { intensive care } \\
\text { units in } \\
\text { Vancouver, } \\
\text { Canada: a case } \\
\text { series. }\end{array}$ & Canada & $\begin{array}{l}\text { From Feb. } \\
21 \text { to Apr. } \\
14, \\
2020\end{array}$ & $\begin{array}{l}69 \\
{[\mathrm{IQR}] 60-} \\
75) \text { years }\end{array}$ & $\begin{array}{l}38 \\
(32.5 \%) \\
\text { were } \\
\text { female }\end{array}$ & 117 & 74 & 34 & 15 \\
\hline $\begin{array}{l}\text { Auld et a } \\
\text { I(24) }\end{array}$ & $\begin{array}{l}\text { ICU and } \\
\text { Ventilator } \\
\text { Mortality } \\
\text { Among Critically } \\
\text { III Adults with } \\
\text { Coronavirus } \\
\text { Disease }\end{array}$ & USA & $\begin{array}{l}\text { From } \\
\text { March 6, } \\
2020 \text {, to } \\
\text { April 17, } \\
2020\end{array}$ & $64(54-73)$ & $\begin{array}{l}98 \\
(45.2) \\
\text { FEMALE }\end{array}$ & 217 & 165 & 88 & 59 \\
\hline $\begin{array}{l}\text { Hur et al } \\
\text { (25) }\end{array}$ & $\begin{array}{l}\text { Factors } \\
\text { Associated with } \\
\text { Intubation and } \\
\text { Prolonged } \\
\text { Intubation in } \\
\text { Hospitalized } \\
\text { Patients With } \\
\text { COVID-19 }\end{array}$ & USA & $\begin{array}{l}\text { From } 1 \\
\text { march to } \\
8 \\
\text { April,2020. }\end{array}$ & $\begin{array}{l}59 \text { years } \\
\text { (interquartile } \\
\text { range, 47- } \\
69 \text { ) }\end{array}$ & 486 & N/A & 138 & 78 & 21 \\
\hline $\begin{array}{l}\text { Petrilli et al } \\
\text { (26) }\end{array}$ & $\begin{array}{l}\text { "Factors } \\
\text { associated with } \\
\text { hospital } \\
\text { admission and } \\
\text { critical illness } \\
\text { among } 5279 \\
\text { people with } \\
\text { coronavirus } \\
\text { disease } 2019 \text { in } \\
\text { New York City: }\end{array}$ & USA & $\begin{array}{l}\text { From } 1 \\
\text { March to } \\
5 \\
\text { May, } 2020 .\end{array}$ & $\begin{array}{l}54 \text { years } \\
\text { (interquartile } \\
\text { range 38-66 } \\
\text { years) }\end{array}$ & 5279 & N/A & 647 & 170 & 391 \\
\hline
\end{tabular}


prospective

cohort study

\begin{tabular}{|c|c|c|c|c|c|c|c|c|c|}
\hline $\begin{array}{l}\text { Docherty et } \\
\text { al (27) }\end{array}$ & $\begin{array}{l}\text { Features of } 20 \\
133 \text { UK Patients } \\
\text { in Hospital With } \\
\text { covid-19 Using } \\
\text { the ISARIC WHO } \\
\text { Clinical } \\
\text { Characterisation } \\
\text { Protocol: } \\
\text { Prospective } \\
\text { Observational } \\
\text { Cohort Study }\end{array}$ & $\begin{array}{l}\text { United } \\
\text { Kingdom }\end{array}$ & $\begin{array}{l}\text { From } 6 \\
\text { February } \\
\text { to } 3 \text { May } \\
2020\end{array}$ & $\begin{array}{l}73 \text { years } \\
\text { (interquartile } \\
\text { range } 58-82 \\
\text { ) }\end{array}$ & 20133 & $\mathrm{~N} / \mathrm{A}$ & 1658 & 276 & 618 \\
\hline
\end{tabular}

\section{Figures}
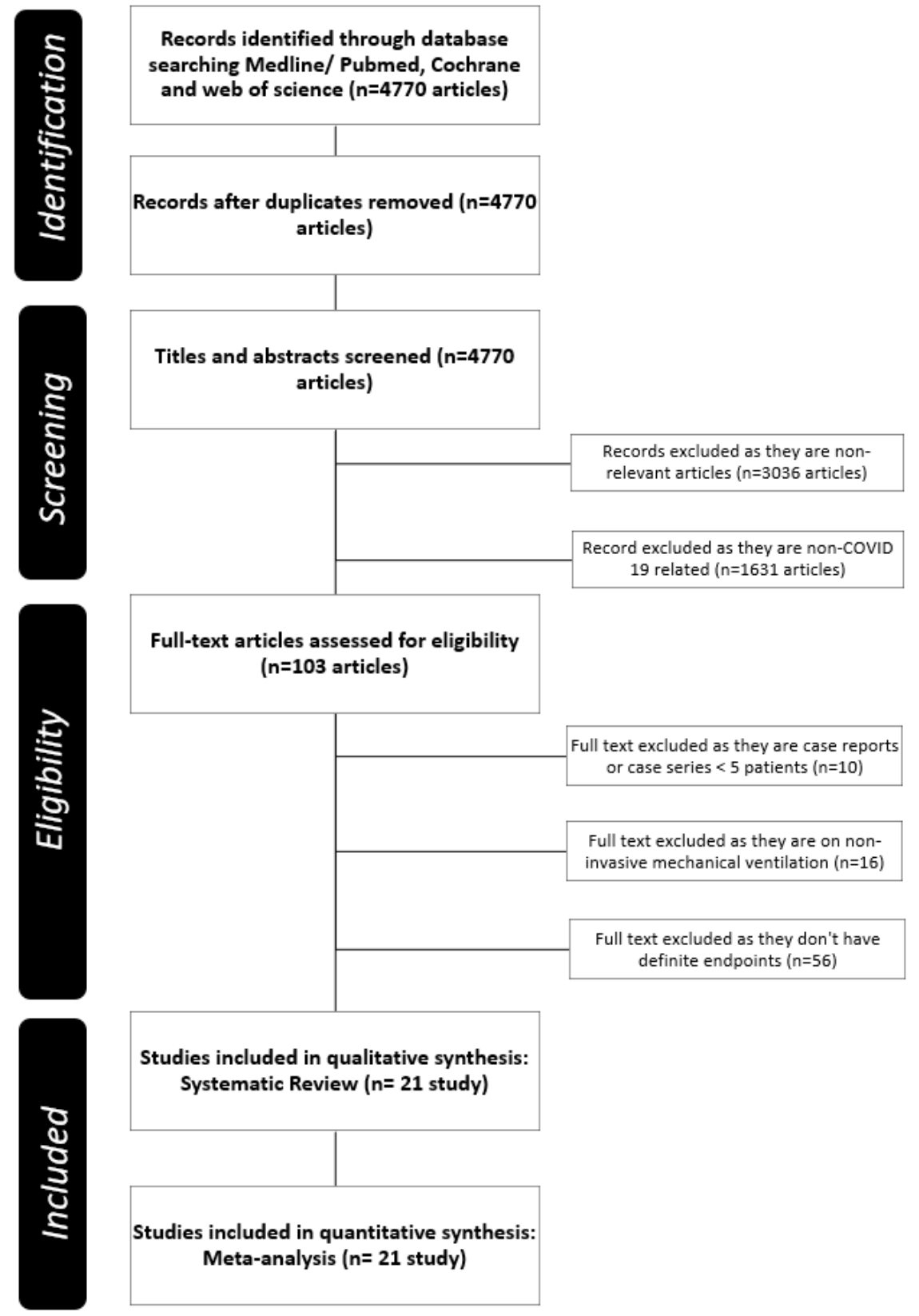
Figure 1

PRISMA flow diagram of study selection

\section{Studies}

Wang et al $2020^{7}$

Pedersen et al $2020^{8}$

Chen et al $2020^{9}$

Yu et al $2020^{10}$

Richardson et al $2020^{11}$

Grasseli et al $2020^{12}$

Zangrillo et al $2020^{13}$

Bhatraju et al $2020^{14}$

Kato et al $2020^{15}$

Wu et al $2020^{16}$

Yang et al $2020^{17}$

Ruan et al $2020^{18}$

Zhou et al $2020^{19}$

Cummings et al $2020^{20}$

Xu et al $2020^{21}$

Argenziano et al $2020^{22}$

Mitra et al $2020^{23}$

Auld et al $2020^{24}$

Hur et al $2020^{25}$

Petrilli et al $2020^{26}$

Docherty et al $2020^{27}$

Overall $\left(I^{\wedge} 2=98.26 \%, P<0.001\right)$
Estimate (95왕 C.I.) Ev/Trt

$0.917(0.696,1.000) \quad 5 / 5$

$0.636(0.352,0.921) \quad 7 / 11$

$0.972(0.896,1.000) \quad 17 / 17$

$0.994(0.976,1.000) \quad 79 / 79$

$0.881(0.846,0.917) \quad 282 / 320$

$0.613(0.576,0.650) \quad 405 / 661$

$0.575(0.422,0.728) \quad 23 / 40$

$0.667(0.449,0.884) \quad 12 / 18$

$0.222(0.000,0.494) \quad 2 / 9$

$0.917(0.696,1.000) \quad 5 / 5$

$0.864(0.720,1.000) \quad 19 / 22$

$0.981(0.928,1.000) \quad 25 / 25$

$0.969(0.908,1.000) \quad 31 / 32$

$0.592(0.511,0.672) \quad 84 / 142$

$0.778(0.586,0.970) \quad 14 / 18$

$0.755(0.686,0.825) \quad 111 / 147$

$0.306(0.177,0.435) \quad 15 / 49$

$0.401(0.322,0.481) \quad 59 / 147$

$0.212(0.132,0.293) \quad 21 / 99$

$0.697(0.659,0.735) \quad 391 / 561$

$0.691(0.661,0.722) \quad 618 / 894$

$2225 / 3301$

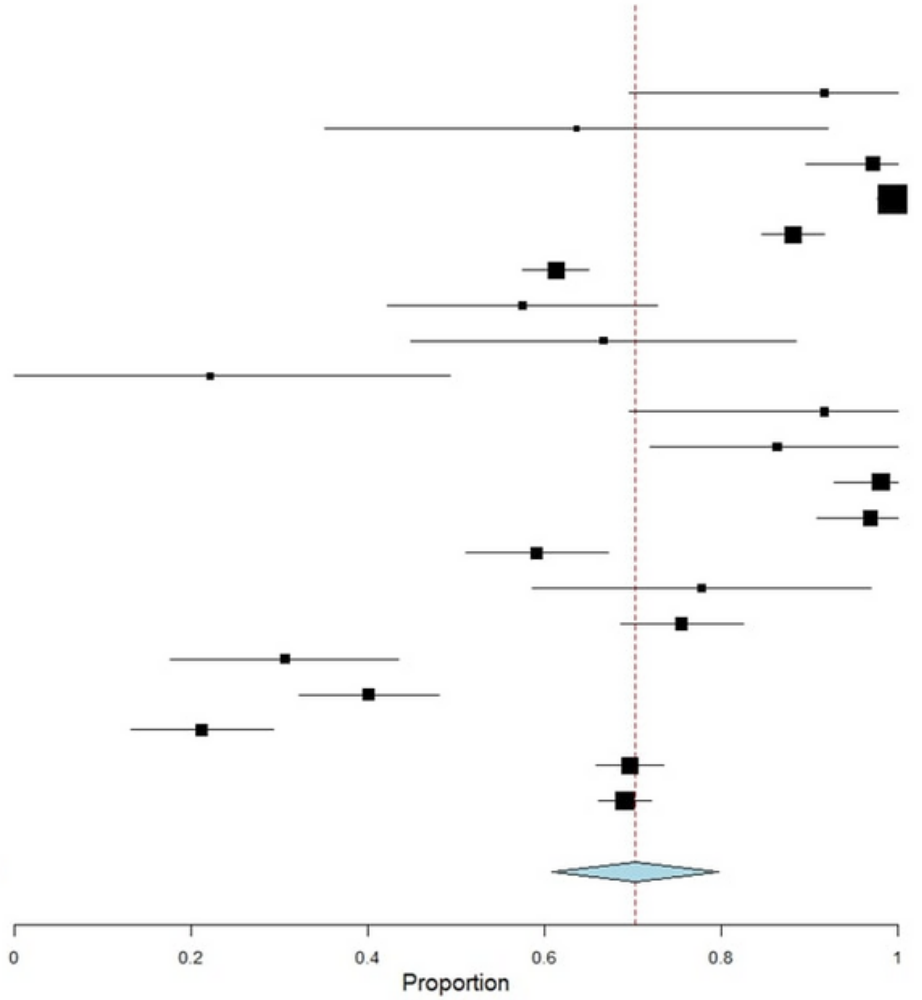

Figure 2

Forest plot of pooled analysis of mortality by random effect model in all studies of IMV with COVID 19 patients 


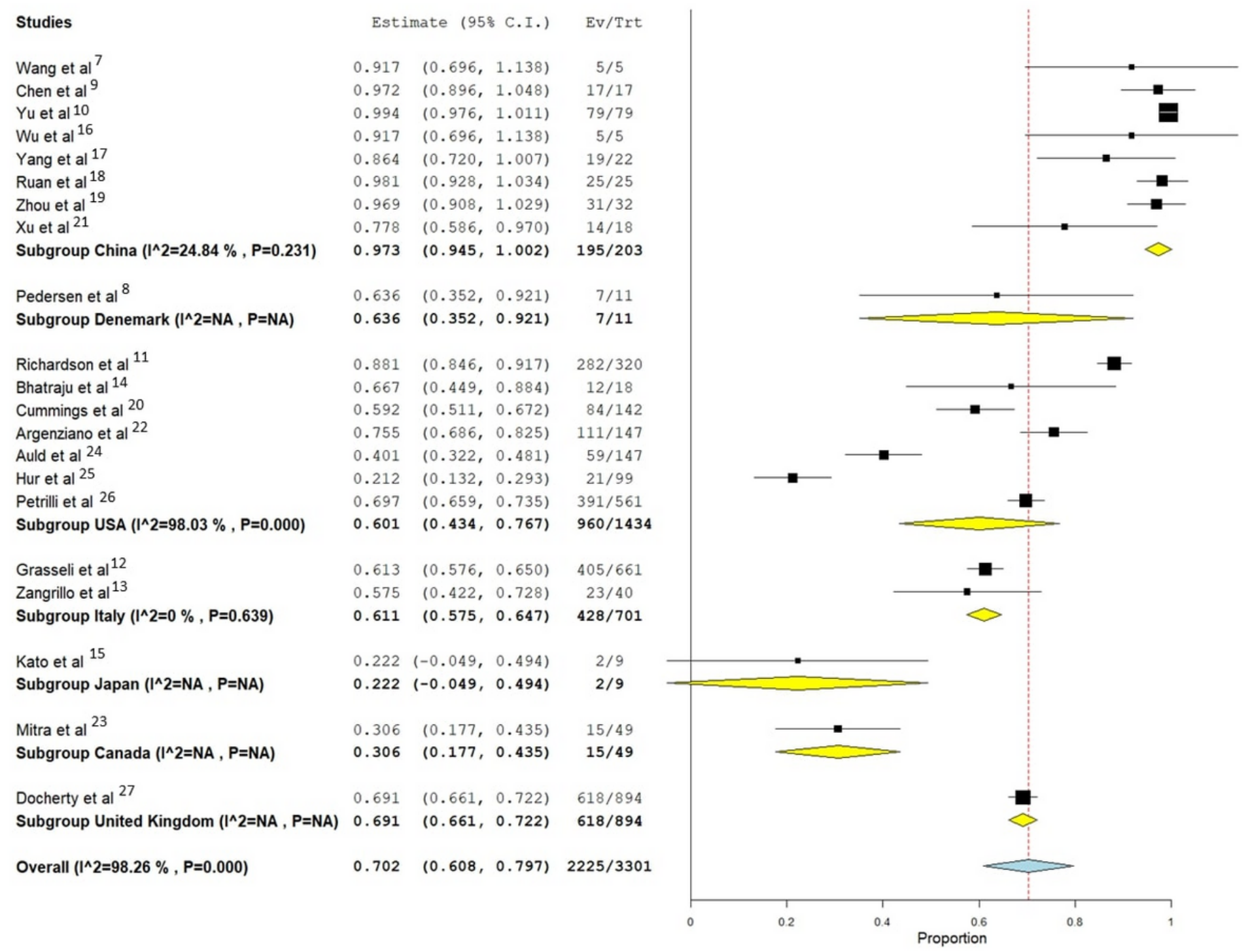

\section{Figure 3}

Forest plot of pooled analysis of mortality by random effect model in all studies of IMV with COVID 19 patients with subgroup division of country of origin 


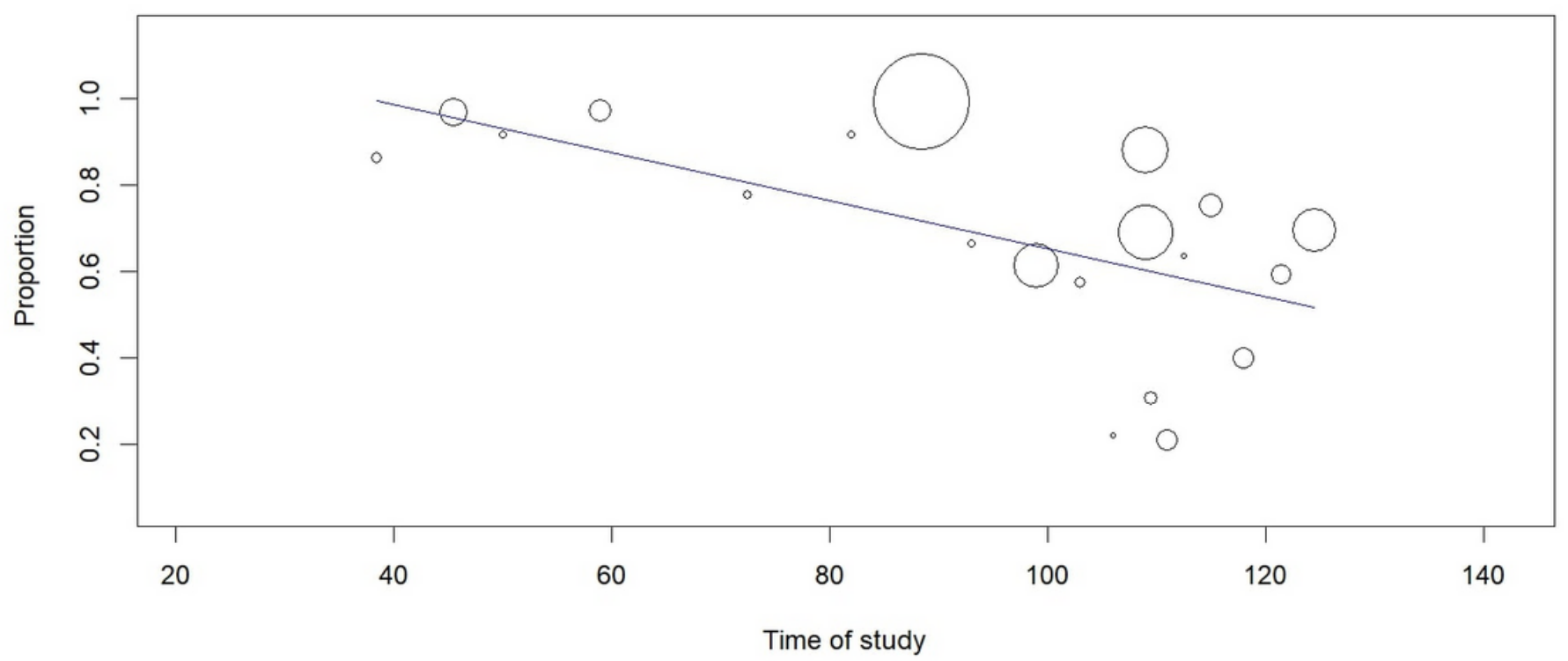

Figure 4

Meta regression for the effect of time on mortality outcome in IMV for COVID-19

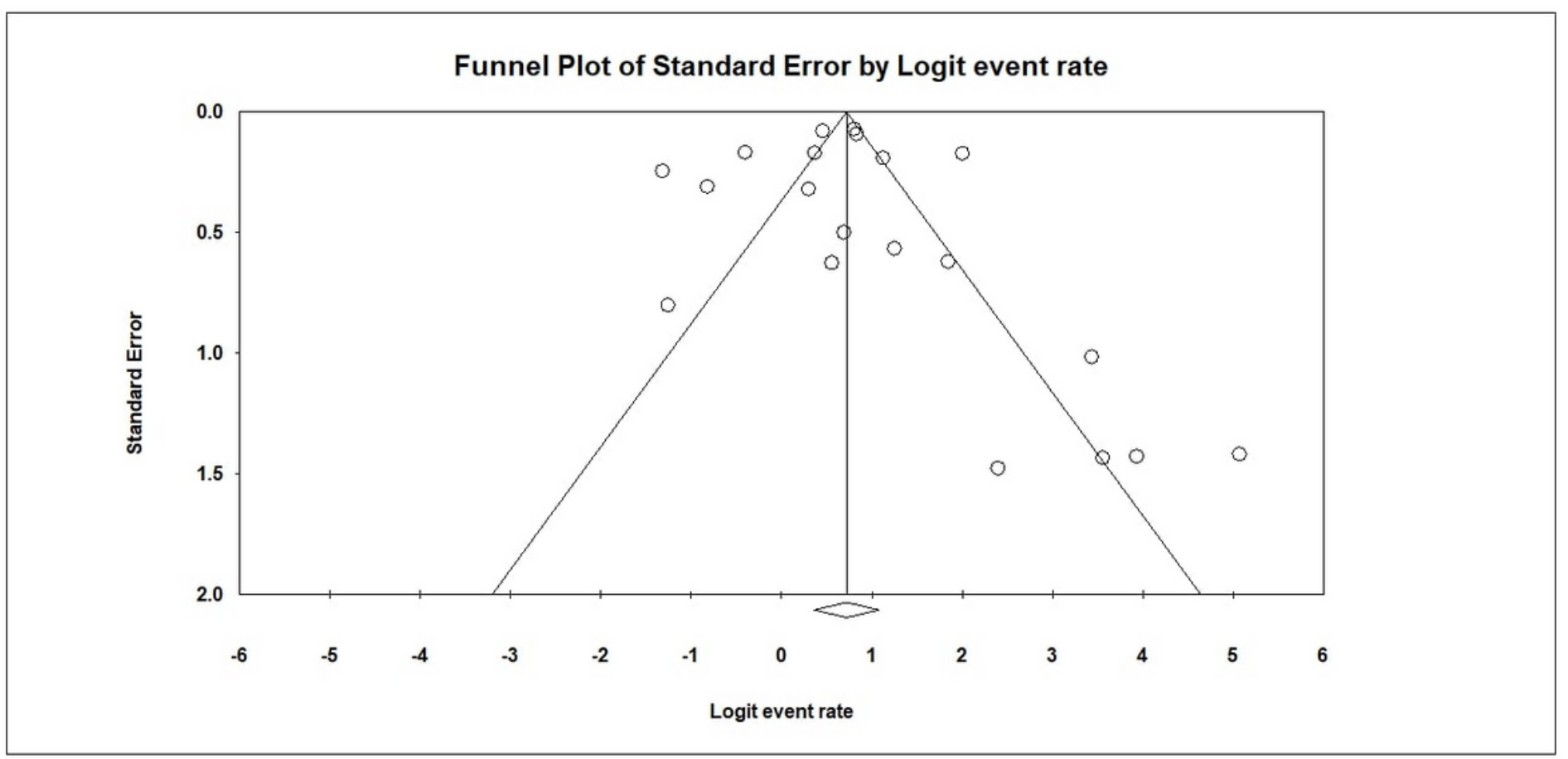

Figure 5

Funnel plot of standard error

\section{Supplementary Files}

This is a list of supplementary files associated with this preprint. Click to download.

- PRISMA2009Checklist.docx 
- PRISMA2009Checklist.docx

Page 16/16 